\title{
GUEST EDITORIAL: THE REGENTS' BIG STICK POLICY
}

\author{
Jean Fallow, Josiane Peltier, \\ and Israel Reyes
}

\section{The Contest}

In August 1993 the University of Iowa Faculty Council, an executive body of the Faculty Senate, made public a proposed policy requiring that if instructors planned to present in class "explicit visual representations of human sexual acts," they should give students "in advance of the presentation information sufficient to enable individual students to make a knowledgeable choice about whether or not to attend that presentation." ${ }^{1}$ The text posed a number of problems in terms of both its specific wording and broader theoretical considerations: Why was (homo) sexual content singled out for warnings instead of, for example, sexism, racism, or violence? Would such a policy engender self-censorship among instructors? Should the Faculty Senate or the Board of Regents have the power to place prior restraints on classroom speech and content? Concerned students mobilized quickly against the policy, arguing that it sanctioned homophobia and violated academic freedom.

On September 28, the students picketed and addressed the Faculty Senate meeting, urging a "no" vote. Several senators indicated from the floor that they were swayed by the arguments presented, and after animated discussion the motion was tabled indefinitely. Although opponents were disappointed that the senators did not reject the policy outright, they viewed the vote as a partial victory for academic freedom. However, the student newspaper announced the following day, "Marvin Berenstein is not happy." The regents President commented, "I think the faculty needs to be more sympathetic to 
students and their parents. They need to understand some material is offensive to people." He added, "I am a little confused. I don't know why they tabled the decision. I'm frankly unhappy that nothing was done. I think it was very clear that the regents wanted a protocol established."

These remarks set the tone for the regents' public comments over the months to come. Their rhetoric would frequently depict faculty as overly intellectual and insensitive to the concerns of "common folks," and then proceed to assert the ultimate authority of the regents, to which the Faculty Senate must eventually bend-whatever the outcome of its own debate. Regent Elizabeth Hendricks, responding to a later and less restrictive policy proposal from the UI Faculty Council, said "the Council doesn't seem to understand how Iowa residents feel about the sex policy." 3 The regents arrogated to themselves the right to speak for "the people" of Iowa, whose interests they represented as irremediably opposed to those of the university. Given this mentality, it was only natural that they would use the authority conferred on them by the conservative governor of Iowa to impose the purported will of their constituency onto instructors paid with public funds. Berenstein's remarks made frequent reference to "taxpayers," and suggested that the regents, valiant defenders of the citizenry, would not allow themselves to be pushed around by campus eggheads. As Berenstein stated in November, "I had half a dozen calls from taxpayers this morning who said, 'Are you going to let the Board of Regents be subjected to the Iowa faculty?'"4

The regents thus laid the burden of showing "sensitivity," however that might be defined, on the shoulders of faculty, while "students and their parents" were constructed as a homogenous group whose members all conveniently agreed with the Board. The Faculty Senate was free to govern itself as long as its decisions remained reasonable in the regents' estimation, but if not, they would step in to discipline their unruly child. "I don't like ultimatums. It is not my style," said Berenstein. "I don't want to impose the regents on this area which I think belongs to faculty. I think the faculty should come up with a solution, but if they can't, then the regents will have to do it for them." 5 This statement reflects one of Berenstein's favorite rhetorical devices: a claim of respect for open discussion, immediately neutralized by the assertion that an open and democratic relationship between regents and university is impossible, ending with a justification for unequivocal imposition of the regents' rule. The illusion of a homogenous whole is conjured up as a means of excluding representations of marginalized acts and people, while the myth of a democratic decision-making process within the institution is invoked only to be decisively shattered: "Let them get off the dime and do what we asked 
them to do," Berenstein spat. ${ }^{6}$ This approach was apparently passed down through the hierarchy, as reflected in a memo to faculty from Dean Aikin following the Franklin Evans video. "Academic freedom is one of our most important principles," she wrote. "Yet no freedom is without an accompanying responsibility." 7 Or as rapper Ice-T puts it, "Freedom of speech- just watch what you say!"

Meanwhile, the ad hoc opposition to the policy evolved into the Campaign for Academic Freedom, a group composed of students, faculty, staff, and community members. Throughout the fall semester CAF organized rallies, literature tables, a petition drive which garnered 1400 signatures, and a well-attended "Canned Film Festival" where the films that had elicited reprimands were screened and discussed. CAF adopted the slogan "There's no policy like no policy" and argued that no policy restricting academic freedom was acceptable. Nor was $\mathrm{CAF}$ alone in claiming that the warning requirement chilled free speech: the UI Graduate Student Senate and the Association of Big Ten Students publicly condemned the policy, as did the Des Moines Register and Teachers for a Democratic Culture. Noam Chomsky, informed by CAF of the situation, wrote to Berenstein, "Academic freedom is a delicate plant, easily injured. It has been restricted and undermined many times throughout our history, and merits constant and vigilant defense." 8 Professor Robert O'Neil, Chair of Committee A of the American Association of University Professors (AAUP), sent a letter to Berenstein stating, "Our concern is not only with academic freedom threats posed by banning what may be said or taught in the classroom, but also from rules that constrain or inhibit."9 Similarly, Cryss Farley of the Iowa Civil Liberties Union wrote to Berenstein:

Pre-censorship is the most dangerous of all curtailments of freedom of expression. The imposition by the regents of a policy singling out one category of instructional material for particularized rulemaking imposes a dangerous form of discrimination against selected ideas and discourse in the academic setting. While the ICLU recognizes that the policy imposed by the Board of Regents does not prohibit the use of explicit materials in the classroom, it is only too clear, given the context in which the policy mandate has arisen, that the intent is to suppress one form of expression in the classroom-a de facto prior restraint. Moreover, the policy sets a dangerous precedent for subsequent restriction of other academic discourse; the control of one form of expression based upon content implies the power to control any or all academic discourse. ${ }^{10}$

Mounting opposition from nationally known figures, civil liberties and education groups amounted to, in Berenstein's words, the noise of 
"some newspaper people and a few faculty people."11 Rather than opening a debate on the issue, the regents made "closure" the order of the day. Apparently it was not as important to have a just policy, or a policy that made any pedagogical sense, as it was to have something in place to show that the regents' word was law. As Berenstein put it "We can't dwell on this subject forever. We need closure." 12

Conspicuously absent from the regents' and administrators' rhetoric was any notion of the university as a site of debate for a wide variety of ideas, some of them inevitably unpopular or at odds with the status quo. Instead, they depicted the university as a static institution whose field of inquiry should not exceed what Regent Thomas Dorr termed "accepted social mores." 13 Of course, if such universally accepted standards in fact existed, there would have been no call for a policy in the first place. The conflict laid bare the disparity between the abstract, stated ideals of higher education and the constraints imposed by the university's role as a corporation within a capitalist state.

In October 1993 the regents met in Cedar Falls, vowing to impose a policy of their own since the Faculty Senate refused to do so. The regents outwardly rejoiced that "channels of communication are now open" between students and regents, but they did not engage a single argument presented by opponents of the policy. ${ }^{14}$ At the next Faculty Senate meeting in November, some senators argued for instituting a policy that would mollify the regents while remaining less restrictive than the Board's own text. However, none of the several versions developed by the Faculty Senate were draconian enough to find favor with the regents, and at their December meeting the Board rejected the faculty's attempt at a compromise text. Weary of the ongoing controversy and of being scolded by the regents, President Hunter Rawlings drafted a substitute version over winter break, while most of the opposition was conveniently off campus. Instead of submitting it to the usual democratic vote by the Faculty Senate, he consulted individually with "about 20 " senators before presenting the text to the regents, who approved it at their January meeting. It is particularly unfortunate that the Faculty Senate failed to take a principled stand on the issue, since Rawlings and the regents were able to characterize its unclear stance as a failure and use it as an excuse to unilaterally impose their will.

It is important to realize that although touted as a compromise, Rawlings' policy - the one currently in effect-has a much broader scope than the regents' October version. It requires advance warning not only for materials with sexual content, but also for those deemed "unusual or unexpected," although by whom or according to what criteria remains unspecified. Given the context in which the policy arose, it is clear that these are merely the new code words for anything 
dealing with homosexuality. However, the policy's domain is now much broader than that: it can be used to discipline instructors for presenting any ideas or classroom materials deemed undesirable by the university administration or the Board of Regents.

\section{The Gatekeeper of Culture}

[T] here are ways of constituting power as an easy floating signifier which just leaves the crude exercise and connections of power and culture altogether emptied of any signification. That is what I take to be the moment of danger in the institutionalization of cultural studies in this highly rarefied and enormously elaborated and well-funded professional world of American academic life. ${ }^{15}$

Stuart Hall, "Cultural Studies and its Theoretical Legacies"

But now the fact that they had at once amply met his wishes in all unimportant matters - and hitherto only unimportant matters had come up-they had robbed him of the possibility of light and easy victories, and with that of the satisfaction which much accompany them and the well-grounded confidence for further and greater struggles. Instead, they let $\mathrm{K}$. go anywhere he liked-of course only within the village-and thus pampered and enervated him, ruled out all possibility of conflict, and transposed him to an unofficial, totally unrecognized, troubled, and alien existence. ${ }^{16}$

\section{Franz Kafka, The Castle}

The academic environment, for all its emphasis on innovation and original research, tends to lull faculty and students alike into a deceptive feeling of security. All are purportedly free to participate in open discourse and to challenge the authorities, who benevolently tolerate their criticism. However, this tolerance is not motivated by any sense of fairness or commitment to free speech; rather, it is a survival mechanism that enables the university's power structure to continue to function despite continual attacks on its validity.

The above quote from Stuart Hall, even though it specifically addresses the recent appearance of cultural studies on American campuses, describes to some extent how the university maintains its authority by allowing power to be seemingly dispersed among its many constituent parts. What Hall emphasizes is that even though power appears to be a free floating signifier, it actually has very centralized sites of operations, self-generation and self-preservation. The manner in which the classroom materials policy was conceived and implemented reveals where those sites of power lie: in the hands 
of the regents and the administration. Unless we admit that academic freedom is conceded only by that power, and unless we expose and challenge its mechanisms, we will be much like Kafka's land-surveyor, K.: imprisoned in our little academic "village" with a false sense of mobility, but actually living "an unofficial, totally unrecognized, troubled and alien existence."

One way in which the university bureaucracy validates and perpetuates its authority is to set up an ostensibly transparent dichotomy of internal and external environments. In Achieving Distinction: A Strategic Plan for the University of Iowa (1989), the Strategic Planning Committee states that such planning was instigated "because universities are undertaking a greater variety of tasks internally and facing more uncertain external environments, conditions similar to those that foster strategic planning in the corporate arena." 17 The text goes on to define the "external context" as social, political, economic and demographic, while the "internal conditions" are culture, traditions and administrative structure. ${ }^{18}$

These distinctions are misleading at best. How did the Strategic Planning Committee decide that culture is solely within the internal realm of the university, while the political is a characteristic particular only to the "uncertain" external environment? Are we to believe that when the regents passed the classroom materials policy, or perhaps when campus security searched through the Iowa International Socialist Organization's desk at the Student Activities Center after the CAF demonstration on February 16, these actions were performed solely for reasons of "culture"? And what about this so-called "culture" that the internal environment of the university has developed and enjoys all on its own? Where does it come from, and how did the university gain exclusive rights to it? Of course the university functions politically and there is no doubt that culture exists off-campus. These critiques may seem rather obvious, but why does the Strategic Planning Committee make such simplistic oppositions between academic and non-academic environments in the first place?

Clearly, the University makes the distinction between internal and external not as a way to describe the environment but as a way to control it. The "internal" structure of the university allows the unstable, "external" elements of society in or out. The rhetoric here is xenophobic, characterizing anything that exists "outside" the university as a potential disruption of the internal structure. As Stuart Hall implies in his reservations about the institutionalization of cultural studies on American campuses, the university continually portrays itself as a progressive, liberal institution which allows a variety of opinions to be heard and cultural practices to be scrutinized and debated. However, it is frequently the case that the university allows certain opinions to be expressed only if they are de-politicized and de- 
contextualized. They can then fit more comfortably within the university's self-defined cultural boundaries.

In Achieving Distinction, the university peppers its discourse of control with repeated affirmations of its commitment to diversity. For example, it states that part of the university's mission is "[t]he creation and maintenance of a community of women and men that is multicultural, multiethnic, multiracial, multinational, and respectful of the dignity of all persons . .."19 Two conflicting rhetorics are at work: one which purports to be in favor of cultural diversity, and another which identifies the role of the university as the gatekeeper of culture. It remains to be defined exactly what kind of culture the university already possesses and what kind of external cultural phenomena it will permit to reside within its "diverse" community.

As has been shown in the history of the classroom materials policy, materials dealing with homosexuals and homosexuality are unfavorable and potentially infectious elements that the university does not wish to admit into the domain of its closely-guarded traditions. Because the university makes claims to respect for diversity, it cannot blatantly prohibit the discussion of homosexual issues in the classroom. Therefore, it devises the warning system, which tells students that although the materials they are about to discuss are "cultural," they are not necessarily equal to the cultural traditions officially sanctioned by the university. What this cultural tradition is and how it exists free from the taint of homosexuality remains a mystery, as the university refuses to identify it.

This is how the university administration maintains its control over discourse: by labeling that which it rejects as "external" and failing to label what it accepts. The assumption is that no one will question the propriety of the "internal." The administration and regents would like to believe that they, too, live in an impregnable castle and maintain strict control over their subjects below. As residents of this academic community, we cannot allow ourselves to suffer the fate of Kafka's frustrated character, K., who finds himself at the mercy of the Castle's bureaucratic whims:

In this life it might easily happen, if he was not always on his guard, that some day or other, in spite of the amiability of the authorities and the scrupulous fulfillment of all his exaggeratedly light duties, he might-deceived by the apparent favor shown him-conduct himself so imprudently as to get a fall; and as it were against their will, but in the name of some public regulation unknown to him, might have to come and clear him out of the way. ${ }^{20}$

By allowing certain materials to be stigmatized with a warning, we, too, find ourselves in the position of the "external": that which is 
external to the power exerted by the regents and the administration. It is obvious that the regents and the administration do not want to share that power with either students or faculty, who are treated as strangers on their own territory-in the classroom. If we allow these forces to dictate to us from afar, we will be effectively giving them permission to come and clear us out of the way at the time of their choosing.

\section{The Big Chill}

Some have asked if the policy really affects classroom dynamics, and whether or not requiring a simple warning before presenting any controversial materials does indeed constitute a form of censorship. After all, as the editors of the Iowa City Press-Citizen argue, many other things in our daily lives carry warnings, such as cigarettes, alcoholic beverages and drugs. What the editors fail to note is that warnings accompany these products because they can be harmful or even fatal. The equation of "unusual or unexpected" materials with toxins belies the claim of neutrality, revealing a fear of the unknown as something tainted and potentially deadly. Because the policy is based on this fear, it creates an atmosphere of distrust toward anything that carries a warning. Already instructors and students have begun to feel the effects of this reactionary backlash.

Although the classroom materials policy does not specifically prohibit the presentation of any issues at the University of Iowa, it creates an atmosphere of fear that encourages instructors to shy away from teaching anything controversial, and discourages students from participating in discussion. Robert O'Neil, chair of Committee A of the American Association of University Professors, commented in the Daily Iowan, "If I were a tenured faculty member facing a policy of this kind, I would be wary of using sexually explicit materials. A faculty member will call close ones against himself."21 Moreover, in a letter to Berenstein, O'Neil noted that the policy would eliminate much spontaneity from the classroom and discourage instructors from introducing materials that might be relevant, but which they had not foreseen using at the beginning of the course. He wrote, "a conscientious instructor who inadvertently failed to issue such a warning, or who during the semester discovered and wished to use covered material, would face under this policy a severe dilemma-either use the material in possible violation of the policy, or forego the material and deprive students of a beneficial learning opportunity. In our view, formal policy that forces such a choice is inimical to academic freedom." 22 Indeed, faculty, teaching assistants and students have already begun self-censoring because of this policy, and the issue is no longer limited to sexually explicit materials. If we allow this policy to stand, any form of knowledge, any type of representation in any 
medium can and will fall victim to the mechanism of fear that the regents and the administration have set in motion.

A part of that mechanism is the policy's repeated use of the word "appropriate" or "appropriately." The concept of appropriateness is an ideal vehicle for perpetuating the myth of bourgeois morality as a universally shared norm. In the context at hand, it creates a selfjustifying value system that seeks to silence debate and establish an unbreachable barrier against the infectious, degenerate bacteria swarming just outside the Institution's vulnerable orifices. Like its companion terms, "good taste," "good judgment," and "common sense," appropriateness casts a veil of inviolability over authoritarian actions. The regents and university administration use it in order to cast certain ideas and texts outside the domain of legitimate intellectual inquiry, while jealously guarding their own ideology from exposure and criticism. Within this hermetic system, reasonable people know, simply because they are reasonable, what is appropriate and what is not: Catch-22. Essentially, the controversy over classroom materials has been an attempt by the regents and the administration to appropriate the right to define appropriateness.

\section{Crashing the Gates of Culture}

The administration and regents have used the notion of appropriateness throughout the policy debate to camouflage their highly political position as a neutral one. In fact, UI students come from many different backgrounds and there is no one generic "offensive text" from which they should be protected. Why then have the regents and the administration singled out materials dealing with (homo)sexuality for special treatment? Why have they responded so energetically to the homophobic objections of a handful of students, and ignored the many voices raised in opposition? Clearly they have chosen to champion the cause of a small group of students whose ideology coincides with their own interests. As the authors of "Strike Three" put it, "Insofar as conservatives have been able to control the definition of 'controversial' and thereby accuse their opponents of pushing an agenda, they succeed in naturalizing their own political program." 23 Thus when Pomerantz stated that it was "not up to this university to take it into its hands and force an individual to see something that's against their standards or their culture or their will," he was expressing concern not for the rights of all students, but specifically for those of right-wing, anti-homosexual students. ${ }^{24}$ Served well by the current power structure, the regents-mostly wealthy businesspeople and lawyers appointed by the governor-are naturally threatened by any ideas that challenge the system, and by tex ts that represent the beings and ideas that system seeks to marginalize 
or deny. It is unlikely that the Regents will grace us with a policy to protect the sensitivites of minority students faced with Eurocentric texts in history courses, or of women faced with D.H. Lawrence or Henry Miller texts in literature classes. Again citing "Strike Three," "The non-ideal students, who are gay, lesbian, minority, foreign, leftist, and feminist, are already marginalized by the fact that their sensibilities are never represented as in danger of being offended in the first place; discourses that contradict their worldviews are par for the course, and their silence is expected." 25

This is not to suggest that a policy should be instituted to "protect" these students, for doing so would rob them of one of the most valuable skills an education can offer: the ability to formulate, articulate and defend arguments. Indeed, one of the most pernicious aspects of the current policy is that it degrades the quality of education of the very students it is ostensibly designed to protect. For the institution to intrude and paternally shield students from ideas they dislike betrays both the learning process and the cause of free speech. As undergraduate Brian Smith told the regents at their October meeting, "I am an adult and I do not want or need you to protect me ... We need to preserve academic freedom to assure that the boundaries of knowledge are not sealed for future generations." 26 Surely most ideas that have changed human history have at one time been considered "unusual or unexpected," and a university's function should be to encourage scrutiny and debate of a wide variety of concepts-not to squelch them. The integrity of a learning institution which considers "unusual or unexpected" classroom content as meriting advance warning must be called into serious question.

However, its danger extends far beyond the borders of the Iowa campus. Since this is the first state to impose such a rule, allowing it to stand would set an extremely dangerous precedent for the rest of the country. Although the policy seems laughable in some respects, a slight rightward shift in the political winds could make it an instrument for ideologically-based purges. Moreover, controlling academic discourse has often been a first strike in attacks on wider freedoms, as the history of Nazism in the 1930s and McCarthyism in the 1950s clearly shows. Repressive forces are unlikely to stop at requiring a warning for materials they define as offensive, although it may constitute an effective first step. The situation must be viewed in the context of current efforts nationwide by reactionary groups like the Christian Coalition to eliminate any classroom discussion of ideas or people that do not meet their definition of normality. Already rightwing forces are targeting such "impure" ideas and disciplines as marxism, feminism, poststructuralism, and African-American Studies for elimination from school curricula. The UI policy constitutes a powerful addition to the arsenal of those who are mounting, under the 
guise of the "anti-political correctness" movement, a backlash against the discussion of non-traditional lifestyles, ethnic minorities, and dissenting political viewpoints in the classroom. The policy does not ensure that students will be protected from political indoctrination in the classroom; it merely ensures that political indoctrination will come only from the right, and that it will be cloaked in the ostensibly neutral mantle of "accepted social mores."

Students and faculty must organize to challenge the whole structure that gives an elite, non-elected body absolute power to impose its ideology on state universities, and this challenge cannot remain limited to op-ed pages and critical journals. To have any effect, it must be expressed through direct action against the imposers of the policy, to wit the regents and the university administration. It is a promising sign that at their February meeting in Iowa City, these forces found their lunch disrupted by an angry crowd of 100 people yelling through the doors, "Choke on your lunch!" and anti-policy slogans. The demonstrators then followed the regents and administrators upstairs, briefly disrupting the meeting with chants of "Freedom to teach, freedom to learn" and "Repeal the policy now!" Although an occupation seemed unfeasible given the numbers, the crowd left chanting "We'll be back," promising a long, steamy spring semester for the policy's defenders in positions of power on campus.

\section{Notes}

${ }^{1}$ Faculty Council draft policy, August 24, 1993.

2 Mary Geraghty and Brad Hahn, "Regents displeased with faculty delay." Daily Iowan, October 1, 1993, p. 1 A.

3 Jim Snyder, "Berenstein pans proposal as confusing." Daily Iowan, November 4, 1993, p. 8A.

${ }^{4}$ Ibid.

5 Mary Geraghty, "Regents may force 'sex act' policy on UI." Daily Iowan, November 4, 1993, p. 8A.

6 Tory Brecht and Mary Geraghty, "Regents set policy over UI objections." Daily Iowan, October 21, 1993, p. 7A.

${ }^{7}$ Dean Judith Aikin, memo to faculty, February 10, 1993.

8 Noam Chomsky, letter to Marvin Berenstein, December 16, 1993.

9 Robert M. O'Neil, letter to Marvin Berenstein, November 3, 1993.

${ }^{10}$ Cryss Farley, letter to Marvin Berenstein, December 1, 1993.

${ }^{11}$ Brad Hahn, "Planners hope film fest exposes homophobia." Daily Iowan, November 15, 1993, p. 5A.

${ }^{12}$ Ibid.

${ }^{13}$ Thomas Dorr, remark at Regents' meeting, October 20, 1993.

${ }^{14}$ Marvin Berenstein, remark at Regents' meeting, October 20, 1993.

${ }^{15}$ Stuart Hall, "Cultural Studies and its Theoretical Legacies. In Lawrence Grossberg, et al., eds., Cultural Studies (New York: Routledge, 1992), pp. 277 - 
286.

${ }^{16}$ Franz Kafka, The Castle. Translated by Willa and Edwin Muir (New York: Vintage Books [1930], 1974), p. 74.

${ }^{17}$ University of lowa Strategic Planning Committee, Achieving Distinction: A Strategic Plan for the University of Iowa (1989), p. 4, emphasis added.

${ }^{18}$ Ibid.

${ }^{19}$ Ibid., p. 7.

${ }^{20}$ Kafka, p. 74.

${ }^{21}$ Jim Snyder, “Regents' policy stirs more contention." Daily Iowan, November 9, 1993, p. 8A.

${ }^{22}$ Robert O'Neil, letter to Marvin Berenstein, November 3, 1993.

${ }^{23}$ The Editors, "Strike Three," op cit., p. 4.

${ }^{24}$ Mark Siebert, "Regents wam about explicit sex films in U of I art classes." Des Moines Register, February 18, 1993, p. 1 A.

25 "Strike Three," op cit., p.4.

${ }^{26}$ Brian Smith, remarks before Iowa State Board of Regents, October 20, 1993. 